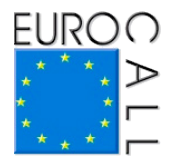

\title{
The alignment of CMC language learning methodologies with the Bridge21 model of $21 \mathrm{C}$ learning
}

\author{
Ciarán Bauer ${ }^{1}$, Ann Devitt ${ }^{2}$, and Brendan Tangney ${ }^{3}$
}

\begin{abstract}
This paper explores the intersection of learning methodologies to promote the development of 21 st century skills with the use of Computer-Mediated Communication (CMC) tools to enhance language learning among adolescent learners. Today, technology offers a greater range of affordances in the teaching and learning of second languages while research shows that student classrooms still continue to concentrate on linguistic competences rather than communicative competences (Gilmore, 2011). The Bridge 21 model, which is technology-mediated, team-led and project-based, brings a particular approach to 21 st-century learning and is distinguished by the mixture and focus of scaffolding and consistency in the application (Lawlor, Conneely, \& Tangney, 2010). An exploratory case study was designed to extend the Bridge 21 model to include spatially-separated teams, based in Ireland and Germany, learning together and enhancing the use of oral and aural skills for second language acquisition. Thirty-six students worked on project-based tasks during a six day workshop focused on the usage of authentic materials and $\mathrm{CMC}$ tools. The findings suggest that using the Bridge21 learning model succeeded in allowing students to collaborate at a distance and to participate in second language acquisition.
\end{abstract}

Keywords: $21 \mathrm{C}$ learning, $\mathrm{CMC}$, native speakers, collaboration, authentic materials.

1. Trinity College Dublin, Ireland; ciaran@bridge21.ie

2. Trinity College Dublin, Ireland; devittan@tcd.ie

3. Trinity College Dublin, Ireland; tangney@tcd.ie

How to cite this article: Bauer, C., Devitt, A., \& Tangney, B. (2015). The alignment of CMC language learning methodologies with the Bridge21 model of $21 \mathrm{C}$ learning. In F. Helm, L. Bradley, M. Guarda, \& S. Thouësny (Eds), Critical CALL - Proceedings of the 2015 EUROCALL Conference, Padova, Italy (pp. 44-50). Dublin: Researchpublishing.net. http://dx.doi.org/10.14705/rpnet.2015.000308 


\section{Introduction}

This paper explores the intersection of a team based, technology mediated, collaborative model of 21st Century (21C) learning (Bridge21) with a ComputerMediated Communication approach to second language learning in order to explore the efficacy of the resulting intervention in terms of both language and 21st century skill development.

There is a strong trend in the literature and with policy makers in various jurisdictions to move towards a model of teaching and learning which is labelled $21 \mathrm{C}$. While the concept is not without its critics, in essence, the $21 \mathrm{C}$ learning agenda promotes the acquisition of key skills, such as problem solving, collaboration and creativity in addition to mastering curriculum content (Gewertz, 2008; Silva, 2009).

Bridge 21 is a particular model of $21 \mathrm{C}$ teaching and learning which is being adapted for use in Irish second level schools (Conneely, Lawlor, \& Tangney, 2013). The model uses a collaborative learning approach within a social constructivist framework to allow groups of learners, in cooperation with expert mentors, to achieve learning goals through the creation and presentation of shared artefacts.

This study extends the Bridge 21 model for use in a distance-based collaborative scenario between German and English language learners. Many of the core principles of the Bridge 21 model are mirrored in the affordances of CMC for language learning, in particular the facilitation of student-led activities with a focus on collaborative inquiry and knowledge construction (Kern, Ware, \& Warschauer, 2004). Technology is viewed as both a means and an end in the learning process as a key aspect of "everyday dimensions of competent social and professional activity" (Thorne \& Black, 2007, p. 149). Chun (2011) provides an excellent overview of the impact of CMC on aspects of language development. This study aims to explore the impact of the collaborative, authentic setting provided by the CMC-mediated Bridge21 model.

\section{Method}

The project was conducted as an exploratory case study in 2013 over a three week period and involved students located in the Bridge 21 learning space in Trinity College Dublin and a post-primary school in Germany. The Irish-based students $(n=17)$ and German-based students $(n=20)$ were divided into four local teams and each team was then paired with a remotely located team. Teams self- 
organised selecting a team name, lead and assigned roles through the project as per the Bridge 21 model. Communication between the spatially separated students took place using Skype and interactions occurred for approximately two hours each day over six days. The objectives of the project were to develop participants' collaborative skills as well as their L2 communicative competence in both written and spoken forms. The projects were structured so as to require local and remote teams to interact in their L2 to co-create some artefacts. Over the two weeks, participants completed four tasks to create multimedia digital artefacts based on information gathered through dialogue (Skype voice and chat functions) with their paired team.

The introductory task involved each team in their L2 creating a "Getting to know you" video of their paired team based on criteria they developed locally during brainstorming. Task 2 involved teams creating an L2 podcast using Audacity based on local radio station themed content with information populated from the spatially-separated team. Task 3 provided an opportunity to reflect on the experience to date. Each team created a website and added materials produced during the workshop. An on-line document was shared between paired teams providing explicit written feedback on their L2, with each native-speaker correcting a non-native speakers' L2 output. The final task involved each team creating a video containing information content researched on-line and outdoors on their local tourist areas. A written blog reflection in their L1 was added to the website by all team participants to complete the project in full.

The data collected included student questionnaires, teacher/mentor interviews and observations, focus group interviews with students and written reflections from task 3. The questionnaires adapted an existing Bridge 21 tool focusing on collaborative and creative skills (Lawlor, Conneely, \& Tangney, 2010) to include items related to language learning and spatially separated collaboration. The intervention was too short to assess language gains, however the data collection instruments do focus on student attitudes and experience of learning and as Centra and Gaubatz (2005) argue "[w]hen a student rates overall instruction as effective, there is a correspondingly high perception of learning, as well as 'actual' learning as measured by course exams" (p. 19).

This paper reports a synthesis of an Etic Coding and Theming investigation (Creswell, 2002) of the student questionnaires, focus groups and interactions to analyse the students' overall experience, attitudes to teamwork and technology, collaboration at a distance, and communication with native speakers over the internet. 


\section{Discussion}

The process in general was an overwhelming endorsement of the workshops and the methods used for the learning experience with $100 \%$ of students rating it "Good" (9) or "Excellent" (23).

Table 1. Themes on the overall experience

\begin{tabular}{|l|l|}
\hline \multicolumn{2}{|l|}{ Themes on the overall experience } \\
\hline Social & Fun/Good experience, Working with new people, Made new friends, \\
\hline Learning & New learning, Friendly atmosphere really helped my learning, \\
\hline Technology & Using technology, More confident with technology, Trying new technology was good \\
\hline Collaboration & $\begin{array}{l}\text { Working in groups to do the projects, German teams were fun to work with, I have more } \\
\text { trust in teamwork now }\end{array}$ \\
\hline Language & Improved fluency, Improved my German, Speaking the language, improved my English \\
\hline
\end{tabular}

As seen in Table 1, the themes emerging from the responses reinforced the positive experience that most of the students shared in the workshops. What is interesting here is that the responses illustrate the integration of language learning with social and collaborative dimensions of the experience:

"It was a fun experience and has definitely improved my social skills and team skills".

"I have now more trust in teamwork".

"I feel over the course of the two weeks I improved on my German and made new friends in both Ireland and Germany".

"As I could understand the Irish students well, I became better and more secure in my English".

Similarly, in response to the question "Does communicating with native language speakers improve oral fluency?", students responded overwhelmingly positively (30 out of 31 positive responses) and their comments illustrate the integration of language, collaboration, and confidence-building (see Table 2). In terms of the impact of the collaborative, project-based intervention, a review of student output from the digital artefacts showed paired teams sharing information in L2 and creating content. In particular, students felt motivated and supported to complete their tasks: 
"When you are being pushed it is easier to learn and be motivated by people around you in a group even more so than the activity itself".

"The other students helped us if we were stuck, we'd ask them and together we made the topics".

Table 2. Language learning with authentic materials

\begin{tabular}{|l|l|}
\hline Themes & Codes \\
\hline Native speakers & Speaking with natives, Local common phrases. \\
\hline Fluency & $\begin{array}{l}\text { Conversation is possible, Improved my fluency, I got to speak a lot, } \\
\text { Spontaneous, Hearing pronunciation, Confidence, Improvisation. }\end{array}$ \\
\hline Learning & $\begin{array}{l}\text { Conversation is possible, Mistakes ok, More understanding, New } \\
\text { vocabulary, Will correct you. }\end{array}$ \\
\hline Collaborating & $\begin{array}{l}\text { Working on projects in German, Peer to peer, Encouragement from } \\
\text { others. }\end{array}$ \\
\hline
\end{tabular}

The findings suggest that using the Bridge 21 learning model afforded students greater opportunities than the regular classroom environment to improve communicative competencies using L2 and authentic materials, e.g. native speakers, music, radio, web content, etc. Students found that communicating with native speakers in an authentic setting, and sharing roles within the group was conducive to language learning and enhanced fluency.

Students reported teams as a very effective way of learning, both locally and remotely, commenting, "It was great to have everybody bringing different skills that enhanced our projects" and "It is a lot easier as part of a team because then you can focus on certain aspects of a project". For example, one Irish-based student noted when speaking to German students, "In the team you have a variety of who you talk to. You're not just talking to the same person over and over again".

\section{Conclusions}

A review of 21 st-century literature shows that we have moved away from an industrial society to an information society (Voogt \& Pelgrum, 2005); students need to use skills which promote critical thinking and problem solving and to work in teams with student-directed learning. The students, by using the Bridge21 model, became active learners and embraced a communicative and collaborative setting for language learning. Students commented "It helped me speak more freely in English and I have more trust in teamwork as I improved my vocabulary", and "I was able to speak more characteristically with them", reinforcing the benefits of providing a real-life environment to participate more in the target language. 
In respect to language learning, students commented, "If there were words you weren't sure of or how to pronounce them, when hearing the German speakers saying them it helps you learn" and "By native-speaking I obtained an impressive will to speak English". This drive to use authentic materials and not rely on text books mirrored the findings of Gilmore (2007) and the lack of diverse learning methods in the classroom.

\section{Acknowledgements}

We would like to thank the students who took part in this for all their enthusiasm, dedication, hard work, and also the Bridge21 team and staff of Bischof von Lipp Schule in Mulfingen.

\section{References}

Centra, J. A., \& Gaubatz, N. B. (2005). Student perceptions of learning and instructional effectiveness in college courses. ETS Student Instructional Report (SIR). Retrieved from https://www.ets.org/Media/Products/perceptions.pdf

Chun, D. M. (2011). Developing intercultural communicative competence through online exchanges. CALICO Journal, 28(2), 392-419. doi:10.11139/cj.28.2.392-419

Conneely, C., Lawlor, J., \& Tangney, B. (2013). Technology, teamwork and 21st century skills in the Irish classroom. In K. Marshall (Ed.), Shaping our future: how the lessons of the past can shape educational transformation. Dublin: Liffey Press.

Creswell, J. W. (2002). Educational research: planning, conducting, and evaluating quantitative and qualitative research. Boston: Pearson Edition.

Gewertz, C. (2008). States press ahead on '21 st-century-skills'. Education Week, 28(8), 21-23.

Gilmore, A. (2007). Authentic materials and authenticity in foreign language learning. Language Learning, 40(2), 97-118. doi:10.1017/s0261444807004144

Gilmore, A. (2011). Japanese learners' communicative competence with authentic materials. Language Learning, 61(3), 786-819. doi:10.1111/j.1467-9922.2011.00634.x

Kern, R., Ware, P., \& Warschauer, M. (2004). 11. Crossing frontiers: new directions in online pedagogy and research. Annual Review of Applied Linguistics, 24, 243-260. doi:10.1017/ S0267190504000091

Lawlor, J., Conneely, C., \& Tangney, B. (2010). Towards a pragmatic model for group-based, technology-mediated, project-oriented learning-an overview of the B2C model. Technology Enhanced Learning. Quality of Teaching and Educational Reform, 602-609. doi:10.1007/9783-642-13166-0_84

Silva, E. (2009). Measuring skills for 21st-Century Learning. The Phi Delta Kappan, 90(9), 630-634. 
Ciarán Bauer, Ann Devitt, and Brendan Tangney

Thorne, S. L., \& Black, R. W. (2007). Language and literacy development in computer-mediated contexts and communities. Annual Review of Applied Linguistics, 27, 133-160. doi:10.1017/ s0267190508070074

Voogt, J., \& Pelgrum, H. (2005). ICT and curriculum change. Human Technology, 1(2), 157-175. doi:http://dx.doi.org/10.17011/ht/urn.2005356 


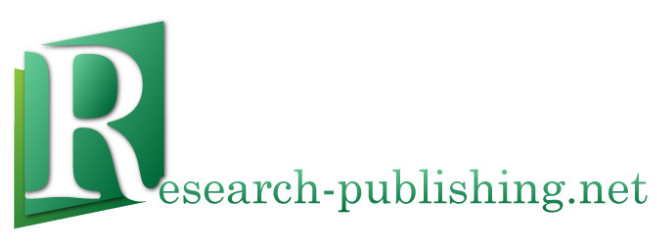

Published by Research-publishing.net, not-for-profit association Dublin, Ireland; info@research-publishing.net

(C) 2015 by Research-publishing.net (collective work)

(C) 2015 by Author (individual work)

Critical CALL - Proceedings of the 2015 EUROCALL Conference, Padova, Italy Edited by Francesca Helm, Linda Bradley, Marta Guarda, and Sylvie Thouësny

Rights: All articles in this collection are published under the Attribution-NonCommercial -NoDerivatives 4.0 International (CC BY-NC-ND 4.0) licence. Under this licence, the contents are freely available online (as PDF files) for anybody to read, download, copy, and redistribute provided that the author(s), editorial team, and publisher are properly cited. Commercial use and derivative works are, however, not permitted.

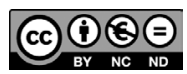

Disclaimer: Research-publishing.net does not take any responsibility for the content of the pages written by the authors of this book. The authors have recognised that the work described was not published before, or that it is not under consideration for publication elsewhere. While the information in this book are believed to be true and accurate on the date of its going to press, neither the editorial team, nor the publisher can accept any legal responsibility for any errors or omissions that may be made. The publisher makes no warranty, expressed or implied, with respect to the material contained herein. While Research-publishing.net is committed to publishing works of integrity, the words are the authors' alone.

Trademark notice: product or corporate names may be trademarks or registered trademarks, and are used only for identification and explanation without intent to infringe.

Copyrighted material: every effort has been made by the editorial team to trace copyright holders and to obtain their permission for the use of copyrighted material in this book. In the event of errors or omissions, please notify the publisher of any corrections that will need to be incorporated in future editions of this book.

Typeset by Research-publishing.net

Fonts used are licensed under a SIL Open Font License

ISBN13: 978-1-908416-28-5 (Paperback - Print on demand, black and white)

Print on demand technology is a high-quality, innovative and ecological printing method; with which the book is never 'out of stock' or 'out of print'.

ISBN13: 978-1-908416-29-2 (Ebook, PDF, colour)

ISBN13: 978-1-908416-30-8 (Ebook, EPUB, colour)

Legal deposit, Ireland: The National Library of Ireland, The Library of Trinity College, The Library of the University of Limerick, The Library of Dublin City University, The Library of NUI Cork, The Library of NUI Maynooth, The Library of University College Dublin, The Library of NUI Galway.

Legal deposit, United Kingdom: The British Library.

British Library Cataloguing-in-Publication Data.

A cataloguing record for this book is available from the British Library.

Legal deposit, France: Bibliothèque Nationale de France - Dépôt légal: décembre 2015. 